\title{
Unskilled blue collar workers: Bourgeois and/or authoritarian? \\ Results from a small scale survey in Belgium
}

\author{
H DE WITTE*
}

\begin{abstract}
In this article, two contrasting theories on the attitudes of unskilled blue collar workers are confronted: the 'embourgeoisement' thesis and the hypothesis of the 'authoritarianism of the working class'. The 'embourgeoisement' thesis states that blue collar workers adopted the attitudes (and life style) of white collar workers, from whom they can no longer be distinguished. Lipset's hypothesis of the 'authoritarianism of the working class', on the other hand, states that blue collar workers more strongly endorse a conservative attitude on socio-cultural matters and a progressive stand concerning socio-economic issues. Both hypotheses are tested using data from a small scale survey $(\mathrm{N}=135)$ among unskilled blue collar workers and lower- and mid-level white collar workers from different large companies in the region of Leuven, Belgium. The results indicate that the interviewed unskilled blue collar workers still hold a set of attitudes that distinguishes them from the interviewed white collar workers. So, the 'embourgeoisement' thesis was refuted. Instead, the unskilled blue collar workers were more conservative on a socio-cultural level, and more progressive concerning socio-economic issues. These results are in line with Lipset's 'authoritarianism of the working class' hypothesis.
\end{abstract}

\section{Keywords}

Embourgeoisement thesis, blue collar workers, white collar workers, working class in Belgium, authoritarianism of the working class, socio-cultural attitudes of occupational groupings.

\footnotetext{
* Prof. Dr. H (Hans) De Witte is full professor at the Department of Psychology of the Katholieke Universiteit Leuven, Belgium. He teaches Work (and Organisational) Psychology and is member of the Research Center Work-, Organisational-, and Personnel Psychology (WOPP) of his Department. His research includes the study of the psychological consequences of job insecurity, unemployment, temporary employment and downsizing, as well as mobbing and stress versus engagement at work, and the impact of work onsocial attitudes.
}

TD: The Journal for Transdisciplinary Research in Southern Africa, Vol. 3 no. 2, December 2007, pp. 279-303 


\section{Disciplines}

Psychology, sociology, Personnel Psychology Belgian Studies.

\section{Introduction}

In this article, two contrasting theories on the attitudes of (unskilled) blue collar workers are confronted: the 'embourgeoisement' thesis and the hypothesis of the 'authoritarianism of the working class'. Although both theories lead to opposing hypotheses, research thus far has focused on just one of them, without confronting it to its counterpart. Research concerning the 'embourgeoisement' thesis mostly focuses on the economic attitudes of workers, whereas the hypothesis of the 'authoritarianism of the working class' refers to economic as well as non-economic attitudes. So, the confrontation of both theories has the additional advantage of elaborating and testing hypotheses concerning the 'embourgeoisement' thesis using a larger set of attitudes than commonly used.

\subsection{Embourgeoisement of the working class?}

A number of developments since the Second World War have radically changed most West European societies, such as Belgium (for a summary see Middendorp, 1979, 27-33 and 83-87; Van Deth, 1984, 26-33). On a socio-economic level, for example, there has been a clear increase in prosperity, while the development of an extensive social security system has improved economic security for the lower social classes. The structure of the working population changed (with a decrease of blue collar workers and an increase of white collar employees) and became more complex and heterogeneous (Bundervoet, 1992, 78; Pasture, 1991, 314-315).

There has also been a great deal of change on the socio-cultural front. The populations level of education rose considerably after the Second World War, in addition to which the shortening of the working week and the increase in mass communication increased active leisure pursuits and new opportunities for cultural knowledge. Growing internationalisation led to shrinking communications distances, bringing large parts of the world 'within reach', while advancing urbanisation blurred the boundaries between town and country.

All these developments might have effected the attitudes and life styles of the population. Some authors advocated that the increase in living standards and the rising socio-economic complexity of society have led to a weakening of the conflict between the different social classes (e.g. Middendorp, 1979, 29-31). This, in turn, is said to have reduced 
the militancy and class-consciousness of the working class.

Others have argued that socio-cultural developments have given rise to the creation of homogeneous life styles, in which cultural differences between different sections of the working population have levelled out (see for example, Laermans, 1990, 143-144; Pasture, 1991, 319-321). These assumptions are generally referred to as the 'embourgeoisement thesis'.

This supports the idea that the economic and cultural developments outlined above have led to the working classes adopting middle class life style, attitudes, behaviour patterns and appearance, from whom they can now barley be distinguished (for a summary, see Goldthorpe et al., 1969, 1-29; Kluegel \& Smith, 1981, 45-48).

This 'embourgeoisement thesis' may well have been formulated for the first time at the end of 1800 (Goldthorpe et al., 1969: 3), but became increasingly popular during the fifties. In 1956, Schelsky supported the view that contemporary West German society had evolved into a uniform middle-class society, in which class differences had disappeared (Schelsky, 1956).

In Belgium, too, Van Mechelen claimed as early as 1954 that "an embourgeoisement of the working class is gradually taking place, as a result of which they are adopting the prevailing attitudes in society and coming to accept and profess the same values" (Van Mechelen, 1954, 66).

Kerr stated in 1969 that "The working class not only tends to disappear as a class-conscious and recognisable element in society: it needs to disappear if modern society is to operate with full effectiveness (...). Class consciousness leads to attitudes of class conflict which are incompatible with modern industrialism." (Kerr, 1969, in: Steijn, 1997, 133). Sometimes, special attention was given to the position of unskilled blue collar workers (Van Doorn, 1953). Van Doorn $(1953,78-87)$ supposed that this specific segment of the working class would resist longer to 'embourgeoisement', even though also a vast majority of this category would become 'bourgeois' on the long run. Van Doorn supposed that this process was already "active or even accomplished" in 1953.

Research on the embourgeoisement thesis did not get under way until the start of the 1960s (see e.g. Zweig, 1961). In their influential study of this thesis, Goldthorpe et. al. (1969) subtly refuted this hypothesis. Although the lifestyle and attitudes of the working classes were subject to change, there proved to be no evidence of complete 'absorption' into the middle class. Later research on this thesis resulted in similar conclusions (e.g. Dalia \& Guest, 1975, 291-294; Marshall et al., 1988). In a recent qualitative re-evaluation of the 
study of Goldthorpe et al., Devine (1992, 208-210) concluded that her working class interviewees still held a collective class identity, which distinguished them from the middle classes. However, as Hill notes, these findings did not prevent the revival of the embourgeoisement thesis during the 1980s and early 1990s (Hill, 1990).

\subsection{An elaboration of 'bourgeois' attitudes}

It is, however, not always clear how 'embourgeoisement' should be investigated. Sometimes aspects of lifestyle (such as leisure activities or social networks) are analysed, while others focus on attitudes. In this article we focus on one aspect of the 'embourgeoisement' thesis: the degree to which members of the working class (still) hold attitudes different from the middle classes. The key focus, then, is not on 'lifestyle', but rather on 'culture' in a sociological sense (Van Doorn \& Lammers, 1984, 108). This limitation to attitudes, however, requires some explanation: first, which attitudes should be analysed when comparing blue and white collar workers and, second, what set of attitudes can be considered 'bourgeois'?

In their study of Vauxhall workers in the area of Luton (UK), Goldthorpe, Lockwood, Bechhofer and Platt (Goldthorpe et al., 1969) mostly focused on the economic attitudes of workers (e.g. 'class images', 'aspirations' and 'social perspectives'), and on the political implications of these attitudes (e.g. voting intentions). In defining 'bourgeois' attitudes, they offer us an ideal-typical description of 'traditional working class' and 'traditional middle class' social perspectives (Goldthorpe et al., 1969, 118-121) .

According to these authors, a traditional working class perspective is characterised by a dichotomous conception of the social order: the division between 'us' and 'them' (those in authority) is unbridgeable. Therefore, emphasis is placed on collective action aimed at the protection of collective interests, with trade unionism as most

Goldthorpe et al. also describe two additional characteristics (Goldthorpe et al., 1969, 118-121). Characteristic for the working class is the wish to maintain their standard of living, and the wish to live in and for the future. The corresponding middle class features are the wish to keep up a progressive improvement in consumption standards and an orientation towards the future. These aspects, however, are less relevant for the purpose of this article. 
developed form. Prime value is set on group solidarity. In the corresponding ideal-type for the middle class, the basic conception of the social order is hierarchical and open: given e.g. ability and determination, individuals can move upwards.

The middle class social ethic is an essentially individualistic one: the prime value is that set on individual achievement. The contrast between an individual orientation (typical for the middle class) and a group orientation (typical for the working class) thus seems crucial for these authors in describing the (economic) attitudes of blue and white collar workers.

This description of the core aspects of 'bourgeois' (contrasting with working class) attitudes, offers a good starting point for the elaboration of a broader test of the embourgeoisement thesis, encompassing more than just economic attitudes. In his thorough (both theoretical and empirical) analysis of conservatism, Middendorp (1978 \& 1991) distinguishes two dimensions within conservatism (a socio-economic and a socio-cultural one), and reveals their underlying values: 'freedom' versus 'equality'.

The opposition between progressive and conservative attitudes in the socio-economic domain points to the socio-economic cleavage: the conflicts between 'labour' and 'capital'. Goldthorpe et al. were mostly dealing with this attitudinal dimension. Middendorp's research in the Netherlands shows that the economic opposition between liberalism and socialism lies at the basis of this dimension: those who express progressive attitudes emphasise the unfairness of social inequality and argue for government intervention in the economy and for a more militant trade union policy in order to counter such inequality.

Conservatives express opposition to government interference in the economy and against more militant trade unions. They reject the claim that social differences arise as the result of inequality of opportunity, and stress private initiative and competition between individuals as essential for proper economic functioning. In other words, in the economic domain, progressive individuals are group oriented and stress the value of equality, while conservatives are oriented towards the individual and stress the value of (individual) freedom.

We can thus reformulate the ideal-typical description of social perspectives offered by Goldthorpe et al., by stating that in the economic domain, blue collar workers are supposed to express progressive attitudes, while white collar workers are supposed to express conservative attitudes. Embourgeoisement would mean that blue collar workers would stress conservative attitudes in the economic domain. 
Next to this economic attitudinal dimension, Middendorp also distinguishes a socio-cultural one. The opposition between conservative and progressive on a socio-cultural level relates to the norms and traditions which exist in society with respect to individual private milieu and family life. Ethical themes (such as sexuality and bio-ethics) and more social themes (such as free speech and tolerance towards minorities) are part of this domain. In a conservative sociocultural view, traditional norms in society are emphasised. Thus, for example, there is a preference for the traditional role-division between men and women and support for a stern regime for bringing up children, in which strictness and obedience are key concepts. Those expressing this attitude also support the traditional work ethic in which the duty to work is emphasised. Those who take a progressive stand in the socio-cultural field generally hold opposite attitudes.

Traditional norms and attitudes are relativised - for example, they stress the emancipation of women, the independence of children and support the liberalisation of abortion or euthanasia. Middendorp argues that socio-cultural conservatism is opposed to the basic value of freedom in the cultural domain, since (individual) freedom would affect and damage traditional institutions and traditional norms. Conservatives instead emphasise equality: everyone should adhere to (instead of deviate from) traditions. Individuals with a progressive attitude concerning socio-cultural matters stress (individual) freedom, since they believe that people should choose their own life style, regardless prevailing traditions.

Middendorp's attempt to define socio-cultural conservatism thus can help us to expand the ideal-typical description of 'social perspectives' of Goldthorpe et al. to the socio-cultural sphere. Since, according to Goldthorpe et al., blue collar workers are group-oriented, we can expect them to hold conservative attitudes in the socio-cultural domain, because conformity to the group (and thus the emphasis on equality) is crucial in socio-cultural conservatism. Since the middle class is (supposed to be) oriented towards individual freedom, a progressive socio-cultural stand seems obvious. Embourgeoisement, then, would mean that blue collar workers would stress progressive attitudes in the cultural domain.

\subsection{Or authoritarianism of the working class?}

The introduction of a distinction between economic and cultural conservatism enables us to test, as a second hypothesis, (an aspect of) another classic sociological hypothesis: Lipset's hypothesis on the 'Authoritarianism of the working class' (Lipset, 1959 \& 1981). Lipset starts his analysis with an inventory of characteristics of the working 
class. According to this author, blue collar workers are characterised by a low level of education, isolated occupations, low participation in political and voluntary organisations, little reading, economic insecurity and authoritarian family patterns. He considers these characteristics as indicative of a certain isolation from the dominant cultural and political values in society. He therefore assumes that blue collar workers develop a preference for simplistic solutions to more complex social problems. He refers to this 'unsophisticated view of the world' as 'authoritarianism', inspired by the influential work of Adorno et al. (1950). Next, Lipset makes a distinction between economic and non-economic liberalism. 'Economic liberalism' refers to a redistribution of income, status and power among the classes, and to support of trade unions. This dimension is identical to Middendorp's 'economic progressiveness' discussed above. Blue collar workers, according to Lipset, hold progressive attitudes in the economic domain, since it best serves their economic interests. 'Noneconomic liberalism' refers to (among others) support for civil liberties for political dissidents and civil rights for ethnic and racial minorities. This dimension resembles Middendorp's dimension of 'socio-cultural progressiveness" ${ }^{2}$.

According to Lipset, blue collar workers reject non-economic liberalism, which means that they favour socio-cultural conservatism. Finally, Lipset combines the different concepts of his theory. He proposes authoritarianism as an explanation and as an intermediating link between the social situation of blue collar workers on the one hand, and economic liberalism and non-economic conservatism on the other. So, according to this author, both the more conservative attitude of the working class to socio-cultural matters and their more progressive attitude on the socio-economic front derives from their authoritarianism.

Albeit this theory is controversial (see e.g. Ray, 1982), Lipset's core hypotheses were not refuted for many years and in many studies (see e.g. Lipsitz, 1965; Grabb, 1979; Felling \& Peters, 1986; Middendorp \& Meloen, 1990; Molnar et al., 1994). In a meticulous reconstruction and test of Lipset's theory in the Netherlands (Scheepers et al., 1992),

Middendorp's concept, however, is slightly broader (and therefore more 'rich'), than Lipset's, since it also refers to a larger amount of social traditions and norms (e.g. role-divisions between men and women, and child rearing practices). 
the authors criticise previous research on several grounds. Many studies restrict their test to the analysis of economic attitudes, and ignore cultural aspects. Only few studies analyse the supposed relationships between authoritarianism and both sets of conservatism. None of the reviewed studies examined whether all of the characteristics Lipset assumed to be typical of blue collar workers indeed contribute to the explanation of authoritarianism. Scheepers et al. then tested Lipset's hypothesis in an integral manner. Blue collar workers proved progressive on economic issues and conservative on cultural ones. The latter finding, however, was only due to their lower level of education, and not to belonging to the working class as such. Authoritarianism did influence cultural conservatism, but did not have a positive effect on economic progressiveness. Lipset's hypothesis concerning the effects of authoritarianism as such thus were partly refuted and partly corroborated.

Because research fails to show that authoritarianism mediates the social situation of workers and their attitudes, only the two 'derived' claims of Lipset's hypothesis on the 'Authoritarianism of the working class' will be tested in this article: we shall examine whether members of the working class adopt a more conservative attitude on the sociocultural front than the middle classes, while being more progressive on a socio-economic level.

An additional reason for not adding the concept of 'authoritarianism' to our design relates to our test of the 'embourgeoisement' thesis, since we did not develop an hypothesis concerning authoritarianism in our test of this thesis. In this contribution, we do not aim to explain the attitudinal differences of blue collar workers in terms of aspects of their social situation (e.g. educational level or feelings of insecurity) ${ }^{3}$. We instead wish to confront Lipset's hypothesis on the 'Authoritarianism of the working class' with the embourgeoisement thesis.

The finding that variables related to social class, such the level of education, are more important in explaining the attitudes under scrutiny, therefore is not relevant for the purpose of our research. 


\section{Method}

\subsection{Sample}

Our hypotheses will be tested on the basis of data collected in 1988, in interviews for a study of the 'working class culture' (De Witte, 1990). Since address lists of workers are not available for research purposes, a two stage sampling design was used.

First, companies were selected in order to get access to the addresses of their employees. In order to achieve a more homogeneous sample of employees, the selection of companies was limited to large companies (of at least 100 employees), in one of the major sectors (machining and processing industry and metal sector) of the region around Leuven (Belgium).

In doing so, we tried to increase the mutual comparability of the blue and white collar workers, since they all worked in similar companies. Only eight companies did meet our criteria. Six of them agreed to participate. Second, a random sample of 211 employees was taken from the list of the personnel of these companies.

Only unskilled blue collar workers and white collar workers below management level were included in the study. In order to increase the homogeneity of our sample, only employees with Belgian nationality, who were married (with children), aged between 30 and 45 years old were included in the sample. A total of 135 workers could be interviewed. This represents a response of $64 \%$, which is acceptable, compared to the response to similar surveys (e.g. Felling et al., 1987: 5).

The non-response was not selective: no differences were found between the response and the non-response group with regard to their occupational group, gender or the company they worked for.

The sample consisted of 71 men (52.6\%) and 64 women (47.4\%). The interviewees were divided into three occupational groups: unskilled blue collar workers $(\mathrm{n}=48 ; 35.6 \%)$, lower-level white collar workers $(n=47 ; 34.8 \%)$ and mid-level white collar workers $(n=40 ; 29.6 \%)$. The distribution of these occupational groups according to sex corresponds well with the actual ratios among the population (see De Witte, 1990, 153-154).

The sample was representative of the envisaged population: unskilled blue collar and white collar workers below management level, working in large companies in one of the major sectors of the region around Leuven (Belgium). No difference was found between this population and the sample with regard to aspects such as occupational group, gender or the company they worked for. 


\subsection{Questionnaire}

In addition to background characteristics (such as gender and age), the questionnaire contained a great many questions about the socioeconomic and socio-cultural attitudes of the interviewees. On the basis of five or six items in each case, some twenty concepts were operationalised. Each item could be rated on a 3-point scale, ranging from 'agree' to 'disagree'. Items which, after factor analysis, pointed to a single concept, were combined into a scale, ranging from 0 (maximum rejection of the concept) to 10 (maximum agreement with the concept). For each scale, a reliability analysis was carried out to test the additivity of the items (Cronbach's alpha) ${ }^{4}$. In this article we limit ourselves to ten concepts (or scales), each of which is representative of a particular attitudinal dimension. A factor analysis on these ten scales showed that they could be placed in the two expected attitudinal dimensions, as was also the case in similar studies carried out in the Netherlands (see e.g. Middendorp, 1991; Felling \& Peters, 1986; Scheepers et al., 1994) ${ }^{5}$.

Five attitude scales pointed to socio-cultural conservatism. In order of importance, these were: a traditional work ethic, in which the duty to work is emphasised (7 items, Cronbach's alpha: .72; typical item: "People who do not want to work are idle layabouts"), a strict style of upbringing (6 items, Cronbach's alpha: .62; typical item: "It is better for the children themselves if they are brought up strictly"), emphasis of the obligation of upward mobility (2 items, Cronbach's alpha: .64; typical item: "You should always try to work your way up"), an instrumental work orientation (4 items, Cronbach's alpha: .60; typical item: "You only work to earn money"), and conformist values relating

4 Since the level of education of most respondents is rather low, these reliability coefficients are rather low too, ranging from .60 to .75. This is not surprising, since the level of education influences the consistency of the attitudes of an individual (Bishop, 1976). Research on conservatism therefore consistently reports lower alpha's among low skilled respondents (see e.g. Vollebergh \& Raaijmakers, 1991).

Factor analysis requires variables to be measured at an interval level. A principal component analysis developed for ordinal variables (principals, see Gifi, 1991) however revealed similar results. 
to upbringing ( 3 items, Cronbach's alpha: .75; examples: children must "learn to be polite" and "learn to obey"). The five other scales pointed to a progressive socio-economic attitude. In order of importance, these were: emphasis on the problematic and unjust position of employees in society ('employee consciousness'; 8 items, Cronbach's alpha: .70; typical item: "Most companies treat employees too lightly"), the importance of the trade union movement in defending the position of employees ('trade union consciousness'; 4 items, Cronbach's alpha: .66; typical item: "The trade unions should have a bigger say in running companies"), defence of government intervention in the economy (3 items, Cronbach's alpha: .62; typical item: "The government must take steps to reduce differences in incomes"), complaints about the lack of opportunities for social mobility (5 items, Cronbach's alpha: .60, typical item: "People like me don't really have much chance of getting on in society"), and emphasis on a conflict of interest between employers and employees ('conflict consciousness'; 4 items, Cronbach's alpha: .60; typical item: "In our society, the employers still get rich off the backs of the workers").

\subsection{Hypotheses}

The 'embourgeoisement' thesis can be tested in two ways. On the one hand an evolution over time is assumed, whereby members of the working class gradually adopt the culture of the middle classes. The consequence or result of this development is that, if it were true, there would remain no attitudinal differences between the two classes.

The test of the hypothesis that a process of embourgeoisement has taken place implies a longitudinal design, in which one analyses to which degree the two groups of workers converged over time in terms of attitudes. Since the data reported in this article were collected at only one single moment of measurement (cross-sectional design), we can only test the second way of analysing the embourgeoisement thesis.

This hypothesis relates to the (end) result of the (possible) embourgeoisement phenomenon: the working classes have become bourgeois if they exhibit the same socio-economic and socio-cultural attitudes as the middle classes. As elaborated earlier, embourgeoisement would mean that blue collar workers exhibit the same attitudes as blue collar workers: economic conservatism and cultural progressiveness.

This is our first hypothesis. Lipset's hypothesis on the 'authoritarianism of the working class' is our second hypothesis. We will test whether blue collar workers are more conservative with regard to socio-cultural matters and more progressive on the socioeconomic front compared to white collar workers. 


\subsection{Method}

For each of the ten attitude scales, the scores of the blue collar workers will be compared with the scores of the white collar workers. The hypotheses will be tested in three ways. First, the number of respondents scoring more than 5 (the neutral score) on each 10-point scale will be calculated. This gives us an insight into the percentage of interviewees who (to a greater or lesser degree) agree with the content of each scale. The differences between the three occupational groups with regard to these dichotomised scales will be tested using a Chi-square Test. Next, a (Pearson) correlation will be calculated between the occupational groups and their scores on the various 10point scales. This gives us an insight into the strength of the association between attitudes and occupational groups ${ }^{6}$. These analyses will be carried out for each scale separately. Finally, in order to be able to test our hypotheses in a more global way as well, a total score will be calculated for the two attitudinal dimensions.

In the original research report, the influence of the variable 'gender' was examined using analysis of variance and was eliminated from the scale scores of the three occupational groups using multiple classification analysis (De Witte, 1990, 159 ff.). Multiple classification analysis recalculates the scale scores of the different occupational groups after adjusting for variation accounted for by other (nonmetric) variables, such as gender (Nie et. al., 1975: 409-418). After control for the occupational group, the gender of the interviewees showed no correlation with the two conservatism dimensions. This corresponds with the research literature (for a summary, see De Witte, 1990, 141142). Therefore, the variable 'gender' will be excluded from the following analysis, since this variable causes no differences in the attitudes analysed in this article ${ }^{7}$.

6 In calculating these coefficients, the full range of the scales was used (ranging from 0 tot 10). The variable 'occupational group' is measured at an ordinal level. Therefore, the calculation of eta-coefficients might seem more appropriate. These coefficients were calculated and compared to the reported correlations. Both coefficients, however, were almost identical (the difference never exceeded .01). The Pearson correlations were reported here, since they also give information on the direction of the association.

The comparison of the scale scores of the three occupational groups adjusted for variation accounted for by the variable 'gender', are almost identical to the unadjusted scale scores. 


\section{Results}

\subsection{Comparison of the socio-cultural attitudes of the three occupational groups}

Figure 1 shows the percentage of interviewees in each occupational group who score above the neutral midpoint of each of the five sociocultural attitude scales described above. In addition to the line representing these percentages, the correlation between each scale and the occupational groups is also shown in Figure 1.

\section{FIGURE 1}

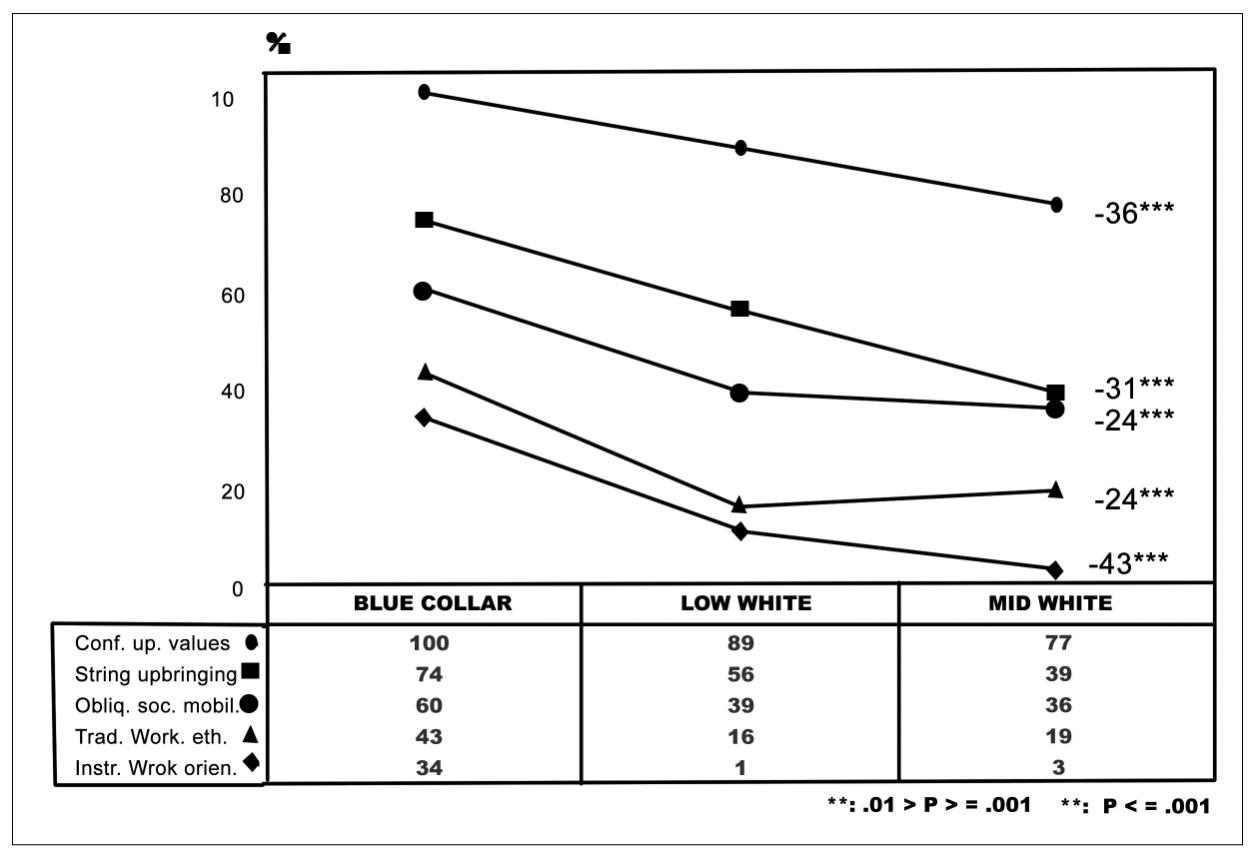

\section{Difference between the three occupational groups on the socio- cultural scales, in \%}

Figure 1 shows that the three occupational groups differ from each other in a statistically significant way with regard to the five sociocultural attitude scales (all differences are at least significant at the .05 level). The same pattern emerges in each case, with unskilled 
blue collar workers scoring more conservative than both groups of white collar workers. As the occupational level increases, the percentage of respondents with conservative attitudes declines. Thus, for example, all unskilled blue collar workers stress that children should learn conformist values during their upbringing, compared to 'only' $89 \%$ of lower-level white collar workers and $77 \%$ of midlevel white collar workers. A similar picture is found with regard to the style of upbringing, where $74 \%$ of the unskilled blue collar workers stress that children should be brought up strictly, compared to only $56 \%$ of lower-level white collar workers. Among the mid-level white collar workers, a majority of $61 \%$ actually reject this attitude.

The unskilled blue collar workers also score higher than the interviewed white collar workers on the obligatory nature of social mobility and the work ethic. The greatest difference between the three occupational groups, however, occurs with regard to their orientation towards work. The work orientation of the unskilled blue collar workers is more clearly instrumental than that of the white collar workers, although it is striking that a majority of all occupational groups rejects a purely instrumental attitude of work.

The fall in conservatism as the occupational level rises is evidenced by the significant negative correlations between the scales and the occupational level (correlations between -.24 and -.43; $\mathrm{P}$ always $<.01$ ). As can also be seen from figure 1 , the strongest associations occur with the scales 'instrumental work orientation', 'conformist upbringing values' and 'strict style of upbringing'.

We can conclude that Lipset's first sub-hypothesis is confirmed: the working class interviewees do indeed adopt a more conservative socio-cultural attitude than the white collar workers. On a sociocultural level, then, these differences mean that the interviewed unskilled manual workers did not become 'bourgeois'.

This becomes even more clearly apparent when we perform a pairwise test of the attitudes of the three occupational groups (testing via a priori contrasts following analysis of variance; see also De Witte, 1990, 219 and 243). The unskilled blue collar workers score significantly more conservative on the five scales selected than the lower-level white collar workers (P always <.05), and than the mid-level white collar workers (P almost always $<.01)$.

The difference between the two groups of white collar workers is only significant in one case (the scale 'instrumental work orientation'). Concerning socio-cultural attitudes, the 'embourgeoisement' thesis thus is refuted: the working class interviewees exhibit different attitudes from the white collar workers and cannot be considered to be 'bourgeois'. 


\subsection{Comparison of the socio-economic attitudes of the three occupational groups}

Figure 2 shows the results of the comparison of the three occupational groups regarding the five socio-economic attitude scales. The correlations between these scales and the occupational groups are also shown in Figure 2.

\section{FIGURE 2}

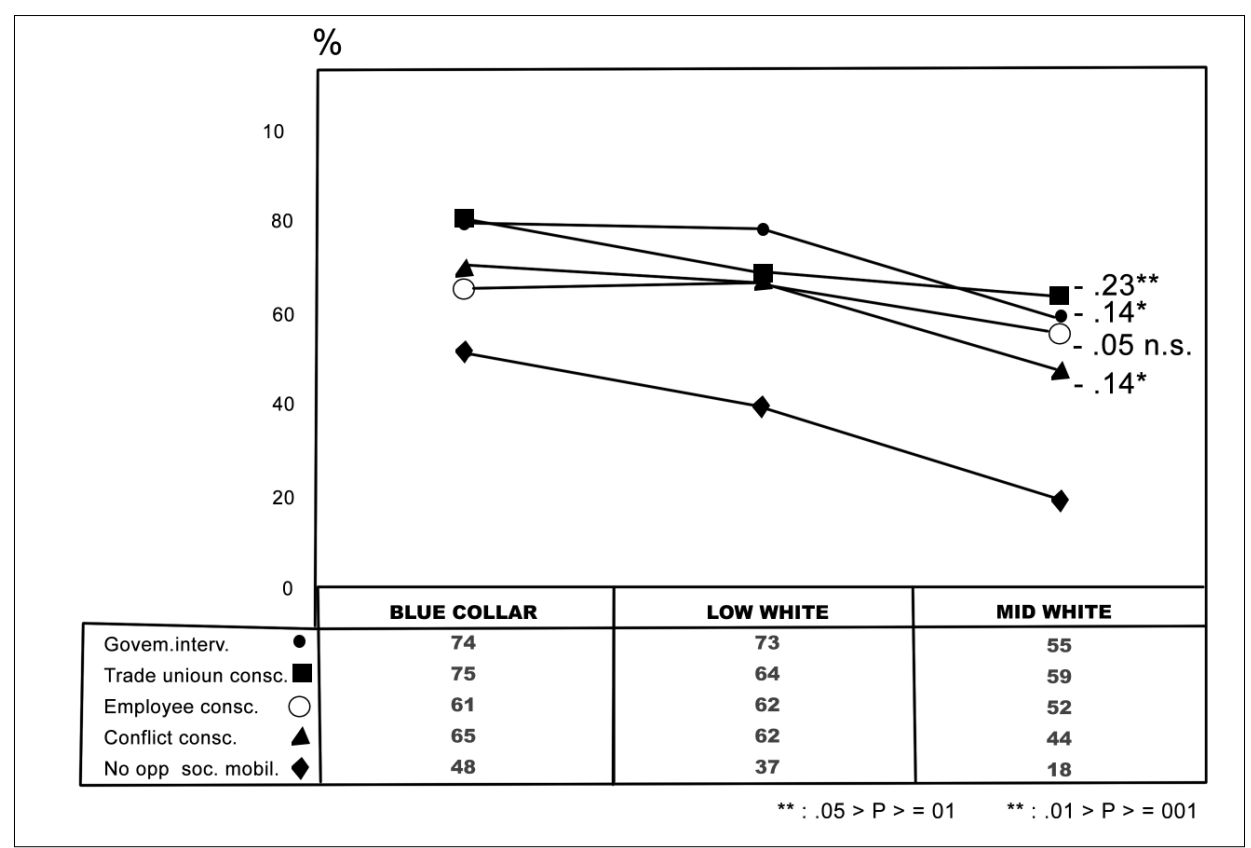

Difference between the three occupational groups on the socioeconomic scales, in \%

Figure 2 reveals a somewhat different pattern from that in Figure 1. Once again, there is a significant difference between the three occupational groups with regard to most of the socio-economic attitude scales, with the percentage of respondents with a progressive attitude falling as the occupational level rises (cf. the significant negative correlations regarding four of the five attitude scales). However, these differences are less pronounced than in Figure 1, as 
is also apparent from the lower correlation coefficients (between -.26 and -.05). Most striking is the difference in the assessment of the opportunity for social mobility. Where almost half $(48 \%)$ of the unskilled blue collar workers consider social mobility to be difficult to achieve, this percentage falls to only $18 \%$ of the mid-level white collar workers. The belief in the importance of the trade union movement in defending the interests of workers ('trade union consciousness') also shows variation from one occupational group to another. Although a majority of all occupational groups express this belief, a greater percentage of unskilled blue collar workers $(75 \%)$ emphasise it than do lower-level white collar workers (64\%) and middle-level white collar workers (59\%).

A majority of both the unskilled blue collar workers and the lowerlevel white collar workers stress the need for government intervention in the economy; the percentage of mid-level white collar workers with this attitude is lower, however. A similar pattern is observed with regard to the attitude that the interests of employers and employees are not easily reconcilable ('conflict consciousness'): a majority of both the unskilled blue collar workers and the lower-level white collar workers showed agreement with this attitude $165 \%$ and $62 \%$ respectively), while $54 \%$ of the mid-level white collar workers reject it. As regards employee consciousness, there is no significant difference between the three occupational groups.

A small majority of the interviewees from all occupational groups sees the position of employees in Belgian society as being (somewhat) problematic.We can conclude that the second sub-hypothesis of Lipset is also confirmed, though only to a weak degree: the unskilled blue collar workers were indeed more progressive on the socio-economic front, but the differences between the various occupational groups (and the strength of these correlations) are weaker than on the sociocultural level.

This is also apparent from the results of a pairwise comparison of the three occupational groups (tested via a priori contrasts following analysis of variance; see also De Witte, 1990, 243).

The unskilled blue collar workers do not differ significantly from the lower-level white collar workers on the five socio-economic scales analysed. There is equally no difference in the socio-economic attitudes of the latter from those of the mid-level white collar workers. The differences between the unskilled blue collar workers and the mid-level white collar workers are, however, significant ( $\mathrm{P}$ always $<.05)$, with the exception of the employee consciousness scale. We can conclude that on the socio-economic level as well, there is a sufficiently large difference between the various occupational groups to reject the embourgeoisement thesis. 


\subsection{Synthetic picture of the attitudes of the three occupational groups}

We limited the above analysis to a separate analysis of five attitude scales for each attitudinal dimension. By calculating overall scores, our hypotheses can be tested in a more synthetic way. To this end, factor scores were calculated, which gave a total score for each dimension. The scores on the socio-economic dimension were recoded, so that the highest score became the lowest, and the lowest score became the highest. Since research shows that this dimension ranges from 'progressive' to 'conservative' (Middendorp, 1991), we can consider this recoded score as a measure of socio-economic conservatism. The average total factor scores of the three occupational groups on the two dimensions are shown in Figure 3, which also shows the correlations between the variable 'occupational group' and the two attitudinal dimensions.

\section{FIGURE 3}

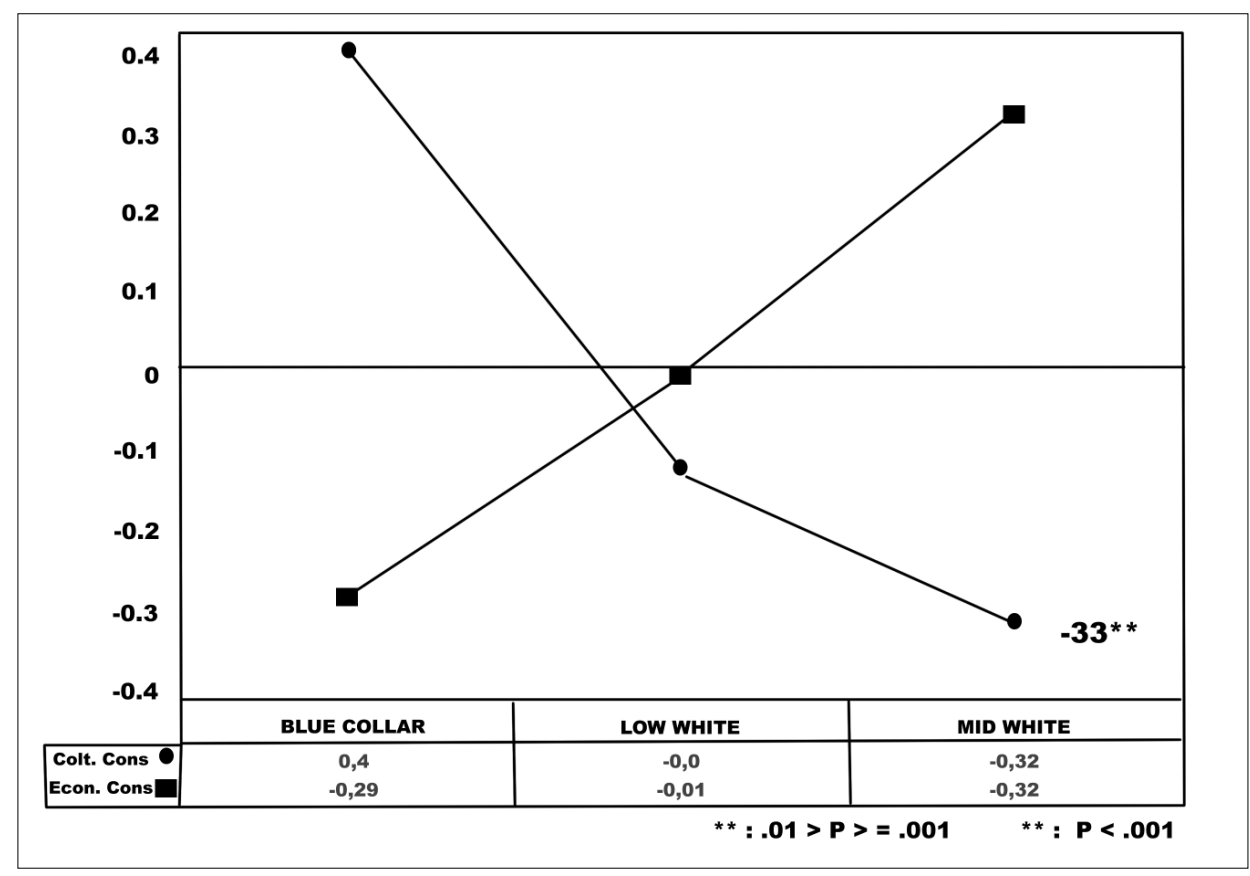

Factor scores of the three occupational groups for socio-cultural and socio-economic conservatism 
Figure 3 confirms Lipset's hypotheses. As the level of the occupational group increases, their socio-economic attitudes become increasingly conservative, while becoming more progressive on the socio-cultural front (test of the factor scores via analysis of variance; $\mathrm{P}<.01$ in both cases). The working class interviewees, then, hold more conservative attitudes in the socio-cultural domain, but are more progressive with respect to socio-economic issues. Their 'culture' in terms of attitudes therefore differs from that of the interviewed white collar workers, so that we can conclude that the embourgeoisement thesis is not confirmed. This is also apparent from the results of a pairwise test of the factor scores of the three occupational groups (testing of a priori contrasts following analysis of variance). The socio-cultural attitudes of the unskilled blue collar workers differ significantly both from those of the lower-level white collar workers $(\mathrm{P}<.01)$ and those of the midlevel white collar workers $(\mathrm{P}<.001)$.

The scores of the two groups of white collar workers do not differ significantly from each other. On a socio-economic level, the only significant difference is between the unskilled blue collar workers and the mid-level white collar workers. The score of the lower-level white collar workers does not differ significantly from that of the unskilled blue collar workers or that of the mid-level white collar workers. This is in line with the observations reported above. The observation that the differences in socio-economic attitudes between the three occupational groups are slightly smaller than the differences in socio-cultural attitudes is also shown by the slightly higher correlation between the occupational group and the degree of sociocultural conservatism.

\section{Summary, discussion and conclusions}

\subsection{Summary of research findings}

The interviewed unskilled blue collar workers in this study still had a 'culture' of their own, that distinguished them from the interviewed white collar workers. Generally speaking, they were more conservative on a socio-cultural level, supporting to a greater degree than the middle class the traditional norms and values with regard to matters such as the family, bringing up children and work. On a socio-economic level, however, the interviewed blue collar workers were more progressive, more frequently displaying dissatisfaction with their position in society (cf. the emphasis on the impossibility of social mobility), and wishing powerful organisations such as the government and the trade unions to bring about change. These observations are in line with our second hypothesis: (the two 'devired' 
subhypotheses of) Lipset's 'working class authoritarianism' hypothesis. That part of the 'embourgeoisement' thesis, that claims that the working class at present holds the same attitudes as the middle class, could not be confirmed.

\subsection{Discussion}

However, the empirical data on which this article is based are obviously limited in several respects. This is, after all, a small-scale study which was geographically restricted to just one region in Belgium (Leuven and its environs). Only a limited range of occupational groups was included in the study (e.g. professionals were excluded), and the spread according to size of company and employment sector was also restricted. The sample of blue collar workers was equally limited: unskilled blue collar workers were taken as the main comparison group, rather than skilled or affluent manual workers, as in Goldthorpe et al.'s famous study.

The degree to which skilled manual workers became 'bourgeois' (or 'authoritarian') was therefore left out of consideration in this study. These limitations stress the importance of future research, in which the attitudes of larger and more heterogeneous samples of blue and white collar workers should be analysed (see e.g. De Witte, 1994a). Future research is also needed to test and integrate more fully the theoretical notions that were elaborated in confronting the 'embourgeoisement' thesis with Lipset's account. This confrontation seems fruitful and deserves more research in the future, since it enables to test a broader conception of the 'embourgeoisement' thesis than commonly used.

\subsection{Conclusions}

To conclude this article, some larger comments will be made concerning our findings.

First of all, we observed that the largest differences in attitudes between the interviewed blue and white collar workers referred to socio-cultural issues. The differences between the occupational groups were less important regarding socio-economic issues. If this finding can be generalised to the Belgian population, then it may be that the two groups have grown closer together in their socioeconomic attitudes over recent decades. However, the necessary comparison data to test this hypothesis are not available in Belgium. 
The observation that unskilled blue collar workers still exhibit a different attitudinal pattern than that of white collar workers is also supported by further analyses of the data collected. Thus the occupational group to which a person belongs can be predicted fairly accurately on the basis of the attitudes of the interviewees (De Witte, 1994b, 87-90). It has also been demonstrated elsewhere that the working class interviewees identify with a different social class than the white collar workers (De Witte, 1992). This suggests that their feeling of class awareness is still intact. Van Doorns' claim in 1953 that even unskilled blue collar workers were in the process of becoming 'bourgeois' (Van Doorn, 1953, 78-87), thus seems unwarranted and premature. This is quite a surprising finding, since Van Doorn made his claim almost half a century ago.

The finding that the interviewed blue collar workers still hold a typical set of attitudes (a 'working class culture') of their own does not, however, imply that this is the same 'culture' as in the past: the working class culture probably has also undergone a certain transformation since the Second World War. Middendorp, for example, shows on the basis of a trend analysis between 1970 and 1992 that the differences in socio-cultural attitudes between blue- and white collar workers exhibit 'trendless fluctuation': sometimes the working class evolves towards the position of the middle class, while on other occasions the scores of both groups tend to diverge (Middendorp, 1994). A similar fluctuation can be noted regarding socio-economic attitudes.

It is, therefore, not self-evident to assume that the working class and the middle class have grown closer 'by definition' when comparing their attitudes. After all, many social phenomena, such as the government policy pursued and the general socio-economic situation of the country, can influence the transformation of the working class culture. Too little is yet known about (and too few studies have been carried out into) what these factors are and in what way they influence this transformation.

The precise way in which working class culture has evolved as a result of these changing social conditions is largely unknown. It deserves more attention in future research.

In this short article there was only room for a description of the attitudinal differences between blue and white collar workers, since the sole aim of this article was to confront two 'classical' theses in sociology. No attempt was made to explain these attitudinal differences. As shown elsewhere, the level of education, the degree to which a person is able to work autonomously and the degree to which a person feels that he has control over his own life ('feelings of personal control') are key factors here (see De Witte, $1993 \&$ 1999). 
Only attitudes have been analysed in this article, when comparing blue and white collar workers. Middendorp's analysis of the core values underlying both attitudinal dimensions, can help us to enlarge our conclusions to values (Middendorp, 1991). His account also enables us to interpret Lipset's paradoxical finding that members of the working class combine conservatism on one level with a progressive attitude on a different level. It finally also enables us to bridge the research findings of Lipset and those of Goldthorpe et al. The combination of economic progressiveness and cultural conservatism is logically consistent when the fundamental values which lie at the basis of the two attitudinal dimensions are made explicit (De Witte, 1990, 12-13). Members of the working class opt in both attitudinal dimensions for the basic value of 'equality'. At the socio-economic level, this means that they reject inequality and that they favour a redistribution of income, status and power among the different social classes, since a progressive attitude in the economic domain best serves their (economic) interests. Concerning socio-cultural issues, they tend to be conservative, stressing the need to adhere to social traditions. In doing so, they again emphasise equality, since they feel that no one should deviate from the traditions in society.

This value orientation is in line with Goldthorpe et al.'s assumption that the orientation towards the group, or the 'collectivity', represents the core element of the working class culture (Goldthorpe et al., 1969, 119). Members of the middle class, by contrast, stress the basic value of (individual) 'freedom' in both attitudinal dimensions. At the socioeconomic level, they stress private initiative and individual competition as essential for proper economic functioning (conservative position). Concerning socio-cultural issues, a similar position is emphasised: individuals should be able to choose to live their life the way they want, regardless prevailing traditions and norms (progressive position). So, in both domains, the individual and individual development are central to their way of thinking. This basic attitude can be typified as 'individualism' (see Goldthorpe et al., 1969, 120121). 
De Witte

\section{References}

Adorno, T. W., Frenkel-Brunswik, E., Levinson, D. J. \& R. N. Sandford 1950. The authoritarian personality. New York: Harper \& Row.

Bishop, G. 1976. The effect of education on ideological consistency. Public Opinion Quarterly 40, 337-348.

Bundervoet, J. 1992. De verhouding arbeiders-bedienden: statistische ontwikkeling en sociologische duiding. In R. Birk, R. Blanpain et al., Statuut werkman-bediende. Arbeidsrechtelijke en sociologische kanttekeningen, 75-109. Belgische Vereniging voor Arbeidsverhoudingen, Brugge: Die Keure.

Dalia, J. \& A. Guest 1975. Embourgeoisement among blue collar workers? Sociological Quarterly 16(3), 291-304.

Devine, F. 1992. Affluent workers revisited. Privatism and the working class. Edinburgh: Edinburgh university press.

De Witte, H. 1990. Conformisme, radicalisme en machteloosheid. Een onderzoek naar de sociaal-culturele en sociaal-economische opvattingen van arbeiders in Vlaanderen. Leuven: Hoger Instituut voor de Arbeid, K.U.Leuven.

De Witte, H. 1992. Subjectieve identificatie met een sociale klasse. Enkele onderzoeksbevindingen in een Vlaamse regio. Tijdschrift voor Arbeidsvraagstukken 8(2), 113-129.

De Witte, H. 1993. Verschillen in conservatisme tussen arbeiders en bedienden: een interpretatie vanuit het concept persoonlijke controle. Gedrag en Organisatie. Tijdschrift voor sociale, arbeidsen organisatiepsychologie 6(2), 57-78.

De Witte, H. (red.) 1994a. Op zoek naar de arbeidersklasse. Een verkenning van de verschillen in opvattingen en leefstijl tussen arbeiders en bedienden in Vlaanderen, Nederland en Europa. Leuven/Amersfoort: Acco.

De Witte, H. 1994b. Een onderzoek naar de arbeiderscultuur in de Leuvense regio. Houden ongeschoolde arbeiders er (nog) andere opvattingen op na dan bedienden? In: H. De Witte (ed.), Op zoek naar de arbeidersklasse. Een verkenning van de verschillen in opvattingen en leefstijl tussen arbeiders en bedienden in Vlaanderen, Nederland en Europa, 74-100. Leuven/Amersfoort: Acco.

De Witte, H. 1999. On the occupational roots of conservatism. Expanding Middendorp's analysis with the concepts of Rotter and Kohn. In: P. Scheepers \& H. De Witte (eds.), Ideology in the 
low countries. Trends, models and lacunae.

Felling, A. \& J. Peters 1986. Conservatism: a multidimensional concept. The Netherlands Journal of Sociology 22, 339-362.

Felling, A., Peters, J. \& O. Schreuder 1987. Religion in Dutch Society 85. Documentation of a national survey on religious and secular attitudes in 1985. Amsterdam: Steinmetz Archive.

Gifi, A. 1991. Non-linear multivariate analysis. New York: John Wiley and Sons.

Goldthorpe, H., Lockwood, D., Bechhofer, F. \& J. Platt 1969. The affluent worker in the class structure. Cambridge: University Press.

Grabb, E. 1979. Working-class authoritarianism and tolerance of outgroups: A reassessment. The Public Opinion Quarterly 43(1), 36-48.

Hill, S. 1990. Britain: the dominant ideology thesis after a decade. In: N. Abercrombie, S. Hill \& B. Turner (eds.), Dominant ideologies. London: Unwin Hyman.

Kleugel, J. R. \& E. R. Smith 1981. Beliefs about stratification. Annual Review of Sociology 7, 29-56.

Laermans, R. 1990. Van verzuild volk naar ontzuild individu. Culturele ontwikkelingen in het naoorlogse Vlaanderen. De Gids op Maatschappelijk Gebied 81(2), 125-147.

Lipset, S. M. 1959. Democracy and Working-Class Authoritarianism. American Sociological Review 24(4), 482-501.

Lipset, S. M. 1981. Political man. The social bases of politics, expanded edition. Baltimore, Maryland: The John Hopkins university press.

Lipsitz, L. 1965. Working class authoritarianism: a re-evaluation. American Sociological Review 30(1), 103-109.

Marshall, G., Newby, H., Rose, D. \& C. Vogler 1988. Social class in modern Britain. London: Hutchinson.

Middendorp, C. 1978. Progressiveness and conservatism. The fundamental dimensions of ideological controversy and their relationship to social class. New York: Mouton Publishers.

Middendorp, C. 1979. Ontzuiling, politisering en restauratie in Nederland. De jaren '60 en '70. Meppel: Druk Boompers Drukkerij.

Middendorp, C. 1991. Ideology in Dutch politics. The democratic system reconsidered 1970-1985. Assen-Maastricht: Van Gorcum. 
Middendorp, C. 1994. De ideologische cultuur van de arbeidersklasse. Evolutie van hun positie op de dimensies 'libertair-autoritair' en 'links-rechts' in Nederland tussen 1970 en 1992. In: H. De Witte (ed.), Op zoek naar de arbeidersklasse. Een verkenning van de verschillen in opvattingen en leefstijl tussen arbeiders en bedienden in Vlaanderen, Nederland en Europa, 119-138. Leuven/Amersfoort: Acco.

Middendorp, C. \& J. Meloen 1990. The authoritarianism of the working-class revisited. European Journal of Political Research 18, 257-267.

Molnar, H., Scheepers, P. \& A. Felling 1994. Cultureel conservatisme en economische progressiviteit onder arbeiders. Lipset's thesen getoetst in zes landen. In: H. De Witte (ed.), Op zoek naar de arbeidersklasse. Een verkenning van de verschillen in opvattingen en leefstijl tussen arbeiders en bedienden in Vlaanderen, Nederland en Europa, 215-243. Leuven/Amersfoort: Acco.

Nie, N., Hull, C., Jenkins, J., Steinbrenner, K. \& D. Bent 1975. SPSS. Statistical Package for the Social Sciences. Second edition. New York: McGraw-Hill Book Company.

Pasture, P. 1991. In de welvaartsstaat (1960-1973). In E. Gerard (ed.), De christelijke arbeidersbeweging in Belgie, Deel 1, 299-348. Leuven: Universitaire Pers.

Ray, J. 1982. The workers are not authoritarian: attitude and personality data from six countries. Sociology and Research 67(2), 166-189.

Scheepers, P., Eisinga, R. \& L. Van Snippenburg 1992. Working-class authoritarianism: evaluation of a research tradition and an empirical test. The Netherlands' Journal of Social Sciences 28(2), 103-126.

Scheepers, P., Lammers, J. \& J. Peters 1994. Religious and class voting in The Netherlands 1990-1991: a review of recent contributions tested. The Netherlands' Journal of Social Sciences 30(1), 5-24.

Schelsky, H. 1956. Gesellschaftlicher Wandel. Offene Welt 41.

Steijn, B. 1997. Post-industrial society: the end of class? In: De Jong, M.-J. \& A. Zijderveld (eds.), The gift of society, 133-148. Nijkerk: Enzo Press.

Van Deth, J. 1984. Politieke waarden. Een onderzoek naar politieke waardeoriëntaties in Nederland in de periode 1970 tot en met 1982. Amsterdam: Ct-press.

Van Doorn, J. 1954. De proletarische achterhoede. Een sociologische critiek. Meppel: Boom \& Zoon. 
Van Doorn, J. \& C. Lammers 1984. Moderne sociologie. Een systematische inleiding. Utrecht-Antwerpen: Uitgeverij Het Spectrum.

Van Mechelen, F. 1954. De psychologie van de arbeidersgroep. Brussel: De Standaard boekhandel.

Vollebergh, W. \& Q. Raaijmakers 1991. Intergenerationele overdracht van autoritarisme. In: P. Scheepers \& R. Eisinga (eds.), Onderdanig en intolerant. Lacunes en controverses in autoritarisme-studies, 61-77. Nijmegen: ITS.

Zweig, F. 1961. The worker in an affluent society. London: Heinemann. 